\title{
JAPAN'S SHIIT FROM PROCESS TO PRODUCT PATENTS IN THE PHARMACEUTICAL INDUSTRY: AN EVENT STUDY OF THE IMPACT ON JAPANESE FIRMS
}

by

\author{
Sumner J. La Croix and Akihiko Kawaura*
}

Working Paper No. 92-1

January 12, 1992

\begin{abstract}
In 1976 Japan expanded the scope of its patent law by extending coverage to newly-developed chemical and pharmaceutical products. Previously the patent law had only provided protection to new production processes for manufacturing chemicals and pharmaceuticals. We use rate of return data from the Tokyo Stock Exchange for Japanese pharmaceutical companies to determine whether these firms gained from the introduction of pharmaceutical product patents. Using two different methodologies we find that the stock price for a portfolio of pharmaceutical firms and for individual firms significantly increased in response to the passage of the 1975 patent law.
\end{abstract}

*Economist, The World Bank, $1818 \mathrm{H}$ Street, N.W., Washington, D.C. 20433; and Professor, Department of Economics and Social Science Research Institute, University of Hawaii, Honolulu, HI 96822; La Croix phone: 808956-7061 or V722780UHMVS.BITNET. The authors thank Carl Bonham, Jay Dratler, $\$$ hewis Freitas, Ted James, Chung Lee, Walter Miklius and seminar participants at the University of Hawaii for their comments. Remaining errors are, of course, our responsibility. The authors thank the Japan-United States Friendship Commission and the East-West Center's Institute for Economic Development and Policy for their support of our research on the

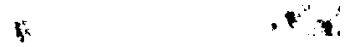




\section{Introduction}

In 1976 Japan expanded the scope of its patent law by extending coverage to newly-developed chemical and pharmaceutical products. Previously the patent law had only provided protection to new production processes for manufacturing chemicals and pharmaceuticals. The impact of expanded patent coverage on a Japanese pharmaceutical firm depended on both the amount and type of its R\&D expenditures. Below we outline two scenarios of how the change in the law could have affected Japanese pharmaceutical firms.

One scenario is that most pharmaceutical firms had R\&D programs directed towards the development of new products. The change in the patent law prevented other firms from entering the market for the newly-developed drug by inventing a new production process to manufacture the drug. Rival firms were constrained after the product patent's introduction to develop a substitute product; since it is almost always more costly to develop a substitute drug than to develop a new production process for an existing drug, the change in the law effectively increased both the term of patent protection for a new product and the present value of the profit stream from its sale. Under this scenario the new law increased the value of the firm's R\&D capital and should have led to an increase in the price of the firm's stock.

A second scenario is that most pharmaceutical firms had R\&D programs directed towards the development of new manufacturing processes. Prior to 1976 a Japanese firm could begin producing any drug if it could develop a new, competitive production process for the drug, and most firms directed some share of their R\&D expenditures towards this goal. With the introduction of pharmaceutical product patents in 1976, Japanese firms were precluded from producing drugs patented under the new law. A firm could only produce a drug protected by a product patent if it obtained a license from the patentholder. Unless these firms could easily reorient their R\&D programs toward developing new products, they were confined (at least in the short run) to developing new production processes for drugs 
developed prior to the change in the law. As newly developed drugs gradually replaced older products, this constraint would have reduced both the firm's market share and its process-oriented R\&D opportunities. The depreciation of the firm's R\&D capital should have led to a decrease in the price of the firm's stock.

Which scenario is more likely for firms in the Japanese pharmaceutical industry? We begin with the assumption that patent policy is an integral part of industrial policy in Japan as it is in other highincome countries. Therefore it seems unlikely that the Japanese government would voluntarily adopt stronger patent protection for foreign and domestic chemical firms if domestic firms were expected to have fewer opportunities under the new system. ${ }^{1}$ Since we find no evidence of pressure from foreign governments or foreign firms to change the patent law in the mid-1970s, there is a strong presumption that the Japanese government and the pharmaceutical industry must have expected industry profits to increase in response to the extended patent coverage. As we discuss below, the Japanese government introduced the stronger system of private property rights in 1976 only after pharmaceutical and chemical firms assured the government that they would prosper in the new legal environment.

In this paper we use rate of return data from the Tokyo Stock Exchange for Japanese pharmaceutical companies to determine whether these firms gained from the introduction of pharmaceutical product patents. Using two different methodologies we find that the stock price for a portfolio of pharmaceutical firms and for individual firms significantly increased in response to the passage of the 1975 patent law.

Section II briefly reviews Japanese patent law and examines the genesis of the 1975 amendments. Section III describes the event study methodology employed to determine whether the change in the patent law generated excess returns for pharmaceutical companies. Section IV describes the stock market data and identifies the event announcement date. Section $V$ presents the results from our empirical tests. Section VI examines the significance of the results and presents an agenda for future research. 


\section{A Short History of Japan's Patent Law}

The first workable patent system in Japan was established by the patent law of 1885 . The main features of the law were molded to conform with the provisions in the 1883 Paris Convention which promoted harmonization of the patent systems in signatory countries. The main features of the 1885 law were: (1) priority was given to the first person to invent; (2) a maximum patent term of 15 years was established, with inventors choosing between terms of 5, 10 or 15 years; (3) product patents for drugs were not allowed; and (4) patents not worked for 7 years became invalid. An 1888 revision of the law specified three categories of goods as unpatentable: ${ }^{2}$

(1) Inventions of food, drink, or luxury goods;

(2) Inventions of medicine or of processes of manufacturing a medicine by mixing two or more medicines; and

(3) Inventions of substances manufactured by a chemical process.

The present form of Japan's patent law was shaped by major revisions enacted in 1921, 1959, 1970, and 1975. The first-to-invent rule was changed to a first-to-file rule in 1921 . The 1959 revision abolished extensions ( 3 to 10 years) of patent terms and limited protection to a maximum of 20 years from the effective filing date and 15 years from the time of the patent's issuance. Amendments in 1970 required the "laying-out open" of patent applications 18 months after their filing and permitted deferred examination of applications up to 7 years after the filing date.

The first move to consider product patents for "new chemical entities" came in March, 1955 when the Japanese Patent Office surveyed 1,352 companies, universities, and academic societies on the introduction of chemical product patents. The replies were evenly split between opponents and proponents of chemical product patents, and the government decided not to pursue the matter any further (Murayama, 1983, p. 1263).

In May, 1970 the revision of the patent law was accompanied by a supplementary resolution in 
the Diet (Parliament) calling for interested parties to work towards the introduction of chemical product patents. In October, 1970 the Japan Patent Association responded to the resolution by surveying its 335 member firms on whether or not they wanted the government to introduce a chemical product patent. Replies were recorded from 233 of the 335 member firms, including 116 of the 157 member chemical and pharmaceutical firms. 59.6 percent of responses from the total sample were positive, while only 8.6 percent were negative (Japan Patent Association, 1971).

In August, 1971 the government asked the Council of Industrial Property Rights to initiate a study on the desirablity of introducing a product patent system. The Council submitted its final report to the Minister of International Trade and Industry on September 18, 1974. The report recommended that product patent protection be extended to new chemical products. A bill was prepared by the Japanese Patent Office and submitted to the next regular session of the Diet on February 17, 1975. ${ }^{3}$

The patent bill was first examined by the upper house, the House of Councilors. After hearings by the Committee on Industry and Commerce, the bill passed the upper house on March 31, 1975. The bill won a majority in the lower house, the House of Representatives, on May 29, 1975 and went into effect on January 1, 1976. Table 1 provides a summary of these events.

\section{Event Study Methodology}

An event study investigates the effects of an event or a class of events by determining how the event affects the value of a firm. ${ }^{4}$ A change in the firm's value is measured by the change in the rate of return on the firm's equity. ${ }^{5}$ When a company's stock realizes a significant excess (positive or negative) return during the "analysis period" surrounding the event announcement, it is inferred that the event had a significant impact on the company's future profitability. ${ }^{6}$

To measure the excess return we use a standard market model that takes explicit account of the return on the market portfolio as well as an individual stock's risk. The advantage of incorporating the return on the market portfolio is that it accounts for aggregate shocks affecting all companies, such as 
changes in pri After controlling for the rate of return the market portfolio the idual component of the firm of eturn eflects information elevant onl to the particular firm and its ind $1+s+r y$.

Our empirical analysis builds the following standard regression equatıon.

$$
\mathrm{R}_{\mathrm{ith}} \quad \alpha_{\mathrm{i}} \quad \beta \mathrm{R}_{\mathrm{mt}} \quad \mu_{\mathrm{it}}
$$

wher

$$
\begin{aligned}
& P_{\text {it }} \text { rate of return stock nth } \\
& R_{m t} \text { rate of eturn ket portfol to in month } \\
& \beta_{i} \operatorname{COV}\left(R_{\text {it }} \mathrm{P}_{\mathrm{rm}^{\mathrm{m}}}\right) / \operatorname{VAR}\left(\mathrm{R}_{\mathrm{mt}}\right) \\
& \boldsymbol{\alpha}_{\mathrm{i}} \quad \mathrm{E}\left(\mathrm{R}_{\mathrm{i}}\right) \quad \mathrm{E}\left(\mathrm{R}_{\mathrm{m}}\right) \\
& \boldsymbol{\mu}_{\text {it }} \text { disturbance stock in month }
\end{aligned}
$$

W th distribution of $\mu_{\mathrm{it}} \mathbf{N}\left(\begin{array}{lll}0 & \sigma^{2}\end{array}\right)$ Parameter $\beta_{\mathrm{i}}$ epresents the risk associated with particular stock Wh stock beta equal the stock refurn is perfectl correlated ith the market of eturn

Izan (1978) created and inder ( 85a, 988) adapted model that enhances this egression specification by du.nmy variables to capture the excess rate of return firm stnck. Dummy arıahl used to capture the permanent changes in the parameters $\left(\boldsymbol{\alpha}_{i}\right.$ and $\left.{ }_{j}\right)$ speci ed in (ll) after th evr takes place and ident fy the ealized during the analysis period $W$ the fol specification to test for ali e-weighted portfol of apanese pharmacerutical firms

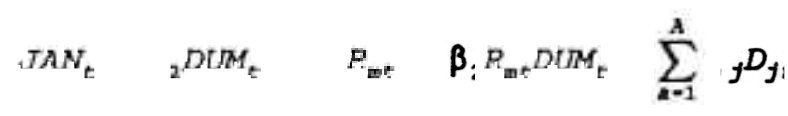


$R_{\boldsymbol{d}}=$ rate of return on the portfolio of Japanese pharmaceutical firms;

$\mathrm{JAN}_{\mathrm{t}}=1$ for January, = 0 otherwise;

DUM $_{t}=1$ for every observation between the first news announcement month and the last observation, $=0$ otherwise;

$D_{j t}=1$ for the $j$ th month in the analysis period, $=0$ otherwise.

Parameters $\alpha_{2}$ and $\beta_{2}$ capture permanent changes in equation (1) after the first news announcement. The JAN dummy variable is inserted to capture the so-called "January effect."

A second test for the presence of excess returns can be conducted by examining the rate of return on the stock of individual companies. Since examining disaggregated data allows estimated coefficients to vary across firms, we can investigate whether the response to the change in the patent law change varies substantially across pharmaceutical firms. This test examines the rate of return for each pharmaceutical firm's stock by decomposing the single equation regression (2) into an N-equation regression system:

$$
\begin{aligned}
& R_{11}=\alpha_{10}+\alpha_{11} \mathrm{JAN}_{\mathrm{t}}+\alpha_{12} \mathrm{DUM}_{\mathrm{t}}+\beta_{11} \mathrm{R}_{\mathrm{mt}}+\beta_{12} \mathrm{R}_{\mathrm{mt}} \mathrm{DUM}_{\mathrm{t}}+\Sigma \Gamma_{1 \mathrm{j}} \mathrm{D}_{\mathrm{jt}}+\mu_{1 \mathrm{t}} \\
& \mathrm{R}_{2 \mathrm{t}}=\alpha_{20}+\alpha_{21} \mathrm{JAN}_{\mathrm{t}}+\alpha_{22} \mathrm{DUM}_{\mathrm{t}}+\beta_{21} \mathrm{R}_{\mathrm{mt}}+\beta_{22} \mathrm{R}_{\mathrm{mt}} \mathrm{DUM}_{\mathrm{t}}+\Sigma \Gamma_{2 \mathrm{j}} \mathrm{D}_{\mathrm{jt}}+\mu_{\mathrm{t}}
\end{aligned}
$$

$$
R_{\mathrm{NT}}=\alpha_{\mathrm{NO}}+\alpha_{\mathrm{N} 1} \mathrm{JAN}_{\mathrm{t}}+\alpha_{\mathrm{N} 2} \mathrm{DUM}_{\mathrm{t}}+\beta_{\mathrm{N} 1} \mathrm{R}_{\mathrm{mt}}+\beta_{\mathrm{N} 2} \mathrm{R}_{\mathrm{mt}} \mathrm{DUM}_{\mathrm{t}}+\Sigma \Gamma_{\mathrm{Nj}} \mathrm{D}_{\mathrm{jt}}+\mu_{\mathrm{Nt}}
$$

Within each equation in the system, we assume the disturbance terms are normally distributed with zero mean and finite variance. The system allows disturbance variances to differ across companies and also permits the contemporaneous covariance of disturbances across firms, $E\left(\mu_{i t}, \mu_{j}\right)$, to be nonzero. Noncontemporaneous covariances, $E\left(\mu_{\mathrm{i}}, \mu_{j+1}\right)$, are assumed to equal zero. A major advantage of using a multi-equation model is that we can test joint hypotheses while a single equation model only tests for average effects (Binder, 1985, p. 173). Since the joint test statistic (Rao's F-statistic) incorporates 
information from the covariance matrix of disturbance terms from the regression system, this allows the disturbances to be heteroskedastic and contemporaneously correlated across equations.

A weakness of our analysis is that the event study methodology is more useful and reliable when employed in the investigation of a class of events than of a single event. ${ }^{10}$ Even when an excess return is detected in the neigborhood of a particular event, there always remains some possibility that it was due to some factor other than the event under investigation. In a multi-event study, the probability of coincidental events declines as the number of event observations increases. Since our analysis is a study of a single event (i.e., the 1975 patent law change), this limitation is clearly present and should be noted. IV. Stock Market Data and the Analysis Period

\section{A. Stock Market Data}

All data on the rates of return on common stocks, including the market portfolio and the industry portfolio, have been provided by the Japan Securities Research Institute (JSRI). Monthly data on the JSRI value-weighted market rate of return for the First Section of the Tokyo Stock Exchange are used as a measure of the rate of return on the market portfolio. Although rate of return data on 27 pharmaceutical firms were originally provided, 11 firms had to be discarded from the sample; they were either too thinly traded to provide a consistent set of data over the entire study period or were listed too recently to provide data prior to the 1975 change in the patent law. Table 2 displays the beta coefficients for the stocks of the 16 remaining companies. Each firm's stock, with the single exception of TAKEDA, has a significant beta coefficient that is positive and less than one.

The 16 firms remaining in the sample are not representative of the entire Japanese pharmaceutical industry. The nature of the event study methodology dictates that the analysis be restricted to firms listed on the Tokyo Stock Exchange. ${ }^{11}$ These 16 publicly-held pharmaceutical firms are concentrated at the larger end of the industry size spectrum and may have $R \& D$ programs that differ in their relative scale and orientation from the R\&D programs of smaller firms. If we assume that smaller firms are more 
likely to be undertaking process $R \& D$, then the limited sample implies that our results will be biased towards finding that Japanese pharmaceutical firms benefit from the changes in the patent law.

\section{B. The Analysis Period}

Choice of the analysis period is critical for an event study. Since an event study tries to identify the response of investors to a particular event, it is important that the researcher identify the period during which unanticipated information is revealed to investors. If the analysis period is incorrectly identified, the event study will fail to correctly reveal the impact of the event on the company's future profitability and is more likely to pick up the effects of other events affecting the firm.

When an event takes a strictly unanticipated form, such as an airplane crash (Chalk, 1986), specification of the analysis period is a relatively simple matter. In the case of changes in the law, determining the date at which investors perceive a higher probability of a new legal environment is more difficult. This is because information about the change in the law is revealed over a period of time, and it is difficult for the analyst to judge a priori which information is most significant. The analysis period may encompass the timeframe between initial proposals for a change in the law and the date when the legislation receives final approval. Binder (1985) reached the pessimistic conclusion that stock returns are ineffective in measuring the effects of changes in the legal environment when the dates on which market expectations change cannot be carefully specified. Other studies, such as Dann and James (1982), are more optimistic that they have successfully determined the announcement date and have derived significant excess returns resulting from regulatory or legislative changes. Although the event we are examining in this study is a change in the statute law, we follow the precedent laid down by regulatory event studies in the handling of the event date: possible event dates are identified from news articles in the major business newspaper.

Announcements of new information on the introduction of chemical product patents were checked in the Nihon Keizai Shimbun, the prime source of information on economic matters for most Japanese 
businessmen. As Table 1 shows, the bill to introduce chemical product patents passed both houses on May 29, 1975 and became a law on June 24, 1975. Relevant news articles were, however, not found on either day. On February 10, 1975, the paper carried a front-page article with a headline reading: "MITI and the Patent Office to submit a bill to strengthen the protection of industrial property rights to the current session of the Diet." The sub-headline read: "Patent rights to be extended to the chemical and pharmaceutical product itself."

Another earlier announcement came on September 18, 1974. It concerned the recommendation which the Council for Industrial Property Rights submitted to the Minister of International Trade and Industry. The main theme of the report was to recommend that MITI and the Patent Office move towards introduction of chemical and pharmaceutical product patents. Although this announcement is probably of smaller magnitude than the February announcement (as the latter reported that the government had actually finished drafting the bill), the effect of the September announcement is examined together with that of the February announcement. The analysis period could extend, therefore, from the Council's issuance of its report (Oct. 1974) to the final passage of the bill by the Diet (May, 1975).

Finally, since this is a single event study, there must be a careful investigation to determine if any other event during the analysis period affected the pharmaceutical firm stock's rate of return. A careful check of articles in Nihon Keizai Shimbun identified only one possibly relevant event. In January, 1975 the Japanese government implemented reductions in its purchase prices for prescription drugs. After reviewing the news articles in Nihon Keizai Shimbun during 1974, we determined that the announcement of the price reductions was made in November, 1974. The price reduction of 1.6 percent was typical of other annual price reductions and was unlikely to have affected the performance of pharmaceutical stocks during the analysis period.

\section{Empirical Results and Interpretation}

Two versions of equation (2) were estimated in order to identify excess returns for a portfolio 
of 16 pharmaceutical companies. Our first specification designates an analysis period extending from the recommendation of the Council in September, 1974 to the bill's passage in May, 1975. The second specification designates an analysis period extending from the submission of the bill in February, 1975 to its passage in May, 1975. We use two different specifications because we are unsure in which month investors' expectations significantly responded to the train of events. Results of these estimates using stock market data from September, 1966 to December, 1979 are presented in Tables 3 and $4 .{ }^{12}$

In both specifications, substantial and statistically significant excess returns were realized on the portfolio of 16 pharmaceutical firms during April and May of 1975. This may reflect the fact that on the last day of March, the bill passed the House of Councilors, thereby increasing the probability that the bill would be approved by the Diet and become law. As long as the same party holds a majority in both houses, the two houses usually have the same verdict on a bill; during 1975 the Liberal Democratic Party (LDP) had substantial majorities in both houses. We conclude that investors in pharmaceutical equities expected that the future profits of these 16 large pharmaceutical firms would increase in response to the introduction of the new product patent.

In contrast, the excess returns in other months are not statistically different from zero. The null hypothesis that coefficients from September 1974 to March 1975 and June 1975 for Case I, and for February, March and June of 1975 in Case II) are jointly equal to zero is not rejected in both cases at the $5 \%$ level by an F-test. ${ }^{13}$

These results are supported by an examination of the volume of trading in pharmaceutical stocks. The share of pharmaceutical firms in trading volume on the Tokyo Stock Exchange is presented in Table 5 for the period from August 1973 through August 1975. The two months in which significant excess returns are observed also exhibit the highest shares of pharmaceutical firms in total trading volume in the sample. ${ }^{14}$ Using a modified version of the test procedure adopted by Jarrell and Poulsen (1989, p. 231), we compare the trading volume during these two months with the trading volume in the 20 previous 
months. ${ }^{15}$ First, we compute the average monthly log volume for the portfolio over the 20 months prior to April, 1975. Then we compute the z-statistic for a particular month by taking the difference between the log of the month's trading volume (log(volume)) and the average monthly log volume (Meanlvol) and then normalizing by the standard deviation of average monthly log volume (S(Meanlvol)):

Z-statistic $=[\log ($ Volume $)-$ Meanlvol $] / S($ Meanlvol $)$.

The z-statistic for April is 3.63 and for May is 4.56; the z-statistics indicate that trading volume in pharmaceutical stocks in both months was significantly higher (at the 5 percent level) than the average trading volume in stocks of other firms. Heavy trading of pharmaceutical stocks during these two months provides a strong indication that investors were reacting to "news" concerning the companies' future profitability.

Now that April and May, 1975 have been identified as the months when the stock market changed its expectation as to the future profitability of pharmaceutical companies, we estimate the disaggregated model (equation 3) using April and May as the analysis period. Since the 16 separate equations are interrelated through their disturbance terms, we employ the technique of seemingly unrelated regression analysis (described above) to estimate excess returns for each firm. Table 6 displays the estimated coefficients for the April and May dummy variables for each of the 16 firms. Fourteen of sixteen firms exhibited positive excess returns for April and May (Table 6, column 3). Half of the sample firms experienced positive excess returns that were statistically significant at the $10 \%$ level in at least one of these two months. The size of the excess returns varied substantially across the sample of firms. Following Binder (1985a) we conducted tests for the joint hypotheses that all excess returns are zero (1) in the May announcement period, (2) in the April announcement period, and (3) the April and May announcement period. Rao has developed a statistic to test joint hypotheses in multivariate regression systems. Rao (1973, p. 555) has shown that the Rao statistic is exactly F-distributed when the number of restrictions tested per equation is equal to or less than two. Rao's F-statistic rejects at the five percent 
level the three hypotheses outlined above that excess returns are zero in the announcement period. ${ }^{16}$

At this stage, it is of interest to examine which characteristics of the firm determine its individual excess return, ER, defined as the sum of excess returns over April and May (Table 6, column 3). Since the introduction of chemical product patents benefits firms with prospects of new pharmaceutical products, we identified characteristics of the 16 firms in our sample that could leave them well-positioned in the new legal environment. Explanatory variables measuring the ratio of R\&D expenditure to sales in 1974 (RATIO), the number of patents granted in 1970-1974 (PATENT), and the ratio of PATENT to R\&D expenditure (R\&DPRO) in 1974 (a proxy for the productivity of R\&D activities) are used as explanatory variables of excess returns. ${ }^{17}$

The coefficient for RATIO has no predicted sign. If the firm's 1974 R\&D expenditures were directed toward developing new products, then its R\&D capital should have appreciated, thereby yielding a positive excess return; on the other hand, if the firm's R\&D expenditures were directed towards developing new production processes for existing drugs, then its R\&D capital should have depreciated, thereby yielding a negative excess return. The coefficients for PATENT and R\&DPRO also cannot be straightforwardly predicted. Although the number of patents granted is a measure of a firm's prior research productivity, firm patents under the pre-1975 patent law are patents on processes (or other inventions) rather than patents on new pharmaceuticals. A firm which is skilled at developing original production processes for an existing product may not have the skills (or find it profitable) to develop new pharmaceutical products. We report regression results in Table 7.

The coefficient of RATIO takes a positive value and the coefficients on PATENT and R\&DPRO are negative, but none of the coefficients are significantly different from zero at even the $10 \%$ level Moreover, the F-statistic rejects significance of the regression at the $5 \%$ level. In sum, the regression fails to explain the variation in profitability across firms. Given the lack of precision in the predicted signs of the explanatory variables, these results are not particularly surprising. 
VI. Conclusion

We have employed the event study methodology to infer whether the 1976 introduction of the chemical product patent was profitable for Japanese pharmaceutical manufacturers. This is equivalent to testing the hypothesis that the government revised its patent law only when domestic producers would profit from the change. Our empirical results reveal a significant positive excess return on a portfolio of pharmaceutical firms' stocks after it became highly likely that the chemical patent bill would eventually pass both houses of the Diet.

The importance of this result goes beyond the experience of Japan. Industrial countries, particularly the United States, have recently made strong "requests" that middle-income and developing countries take measures to provide stronger protection for intellectual property, including pharmaceuticals. ${ }^{18}$ Developing countries have resisted these demands, as they understand that stronger patent protection may injure some domestic industries, at least in the short run. So long as the experience of Japan is not an isolated one, governments will strengthen intellectual property rights only when such moves are beneficial to the domestic industry (or the result of retaliation threats). If this is the case, further harmonization of countries' patent laws will be an extremely difficult goal to achieve, as the harmonization is unlikely to be Pareto optimal. ${ }^{19}$ 


\section{REFERENCES}

Binder, J.J. "Measuring the Effects of Regulation with Stock Price Data." The Rand Journal of Economics, Vol. 16 (1985a), pp. 167-83.

. "On the Use of the Multivariate Regression Model in Event Studies." Journal of Accounting Research, Vol. 23 (1985b), pp. 370-83.

. "The Sherman Antitrust Act and the Railroad Cartels." The Journal of Law \& Economics, Vol. 31 (1988), pp. 443-68.

Brealey, R., and Myers, S. Principles of Corporate Finance. New York: McGraw-Hill, 1984.

Chalk, A. "Market Forces and Aircraft Safety: The Case of the DC-10." Economic Inquiry, Vol. 24 (1986), pp. 43-60.

Dann, L.Y., and James, C.M. "An Analysis of the Impact of Deposit Rate Ceilings on the Market Value of Thrift Institutions." Journal of Finance, Vol. 37 (1982), pp. 1259-75.

Fama E.F., Fisher L., Jensen M.C., and Roll, R. "The Adjustment of Stock Prices to New Information." International Economic Review, Vol. 10 (1969), pp. 1-21.

Gultekin, M.N., and Gultekin, N.B. "Stock Market Seasonality: International Evidence." Journal of Financial Economics, Vol. 12 (1983), pp. 469-81.

Izan, H.Y. "An Empirical Analysis of the Economic Effects of Mandatory Government Audit Requirements." Unpublished Ph.D. dissertation, University of Chicago, 1978.

Jaffe, J., and Westerfield, R. "Patterns in Japanese Common Stock Returns: Day of the Week and Turn of the Year Effects." Journal of Financial and Quantitative Analysis, Vol. 20 (1985), pp. 261-72.

Japan Patent Association. "Kagaku Busshitsu Tokkyoseido Oyobi lyakuhin Tokkyoseidoni Kansuru Ankeito Houkoku (Questionnaire Survey of Chemical Product Patent and Pharmaceutical Patent). " Tokkyo Kanri, Vol. 21 (1971), pp. 451-65.

Jarrell, G.A., and Poulsen, A.B. "Stock Trading Before the Announcement of Tender Offers: Insider Trading or Market Anticipation." Journal of Law, Economics.and Organization, Vol. 5 (1989), pp. 225-48.

Kato, K., and Schallheim, J.S. "Seasonal and Size Anomalies in the Japanese Stock Market." Lournal of Financial and Quantitative Analysis, Vol. 20 (1985), pp. 243-60.

Kawaura, A. "R\&D Rivalry and the Transition from Process to Product Patents: A Case Study of the Japanese Pharmaceutical Industry." Unpublished Ph.D. dissertation, University of Hawaii, 1989.

Keim, D.B. "Size-Related Anomalies and Stock Return Seasonality: Further Empirical Evidence." Journal of Financial Economics, Vol. 12 (1983), pp. 13-32. 
La Croix, S.J. "The Political Economy of Intellectual Property Rights in Developing Countries," in J. Roumasset and S. Barr, eds., The Economics of Cooperation: East Asian Development and the Case for Pro-Market Intervention. Boulder, Colorado: Westview Press, forthcoming 1991a.

$\therefore$ "Property Rights in Computer Software: Some Comments on the Evolving International Framework," in K. Abe and W. Gunther, eds., Econornic, Industrial and Managerial Coordination Between Japan and the USA: A Comparative Analysis. New York: Macmillan Press, forthcoming 1991b.

Murayama, K. "Nihonniokeru Busshitsu Iyaku Tokkyoseido Dounyuno Keikenni Tsuite (On Japan's Experience in Introducing the Product and Pharmaceutical Patent System)." Tokkyo Kanri, Vol 33 (1983), pp. 1261-71.

Prager, R.A. "Using Stock Price Data to Measure the Effects of Regulation: the Interstate Commerce Act and the Railroad Industry." The Rand Journal of Economics, Vol. 20 (1989), pp. 280-90.

Rao, C.R. Linear Statistical Inference and its Applications, 2nd ed. New York: John Wiley \& Sons, 1973.

Sakakibara, S., Yamaji, H., Sakurai, H., Shiroshita, K., and Fukuda, S. The Japanese Stock Market: Pricing Systems and Accounting Information. New York: Praeger, 1988.

Schumann, L. "State Regulation of Takeovers and Shareholder Wealth: the Case of New York's 1985 Takeover Statutes." The Rand Journal of Economics, Vol. 19 (1988), pp. 557-67.

Smith, R.T., Bradley, M., and Jarrell, G. "Studying Firm-Specific Effects of Regulation with Stock Market Data: An Application to Oil Price Regulation." The Rand Journal of Economics, Vol 17 (1986), pp. 467-489

Tinic, S.M., and West, R.R. "Risk and Return: January vs. the Rest of the Year." Journal of Financial Economics, Vol. 13 (1984), pp. 561-74.

Trajtenberg, M. "A Penny for Your Quotes: Patent Citations and the Value of Innovations." The Rand Journal of Economics, Vol. 21 (1990), pp. 172-87. 
Table 1

Outline of Events Leading to the Introduction of the Product Patent

09-18-74 Recommendation by the Council for Industrial Property Rights. Calls for introduction of the chemical product patent.

02-17-75 Government submits patent bill to the House of Councilors (the upper house).

03-31-75 The bill passes the upper house. Moves to the House of Representatives (the lower house).

05-29-75 The bill passes the lower house.

06-25-75 The bill becomes a law.

01-01-76 The law takes effect. 
Table 2

Beta of Stocks of Japanese Pharmaceutical Companies Listed on the Tokyo Stock Exchange

\begin{tabular}{|c|c|c|c|}
\hline Company & $\begin{array}{l}\text { Estimated } \\
\text { beta }\end{array}$ & $\begin{array}{l}\text { Standard error of } \\
\text { estimated beta }\end{array}$ & R-Squared \\
\hline SANKYO & 0.89 & $(0.21)$ & 0.23 \\
\hline TAKEDA & 1.02 & $(0.15)$ & 0.43 \\
\hline YAMANOUCHI & 0.79 & $(0.20)$ & 0.22 \\
\hline DAIICHI & 0.86 & $(0.24)$ & 0.18 \\
\hline DAINIPPON & 0.70 & $(0.16)$ & 0.24 \\
\hline SHIONOGI & 0.81 & $(0.15)$ & 0.33 \\
\hline TANABE & 0.96 & $(0.21)$ & 0.27 \\
\hline YOSHITOMI & 0.67 & $(0.19)$ & 0.17 \\
\hline FUJISAWA & 0.69 & $(0.18)$ & 0.19 \\
\hline BANYU & 0.68 & $(0.14)$ & 0.30 \\
\hline NIPPON SHINYAKU & 0.99 & $(0.25)$ & 0.22 \\
\hline CHUGAI & 0.55 & $(0.27)$ & 0.07 \\
\hline GREEN CROSS & 0.91 & $(0.33)$ & 0.12 \\
\hline EISAI & 0.68 & $(0.17)$ & 0.22 \\
\hline ROHTO & 0.61 & $(0.17)$ & 0.18 \\
\hline TAISHO & 0.91 & $(0.20)$ & 0.26 \\
\hline
\end{tabular}

Each estimate is based on 60 monthly observations between September, 1969 and August, 1974. The Japanese Security Research Institute (JSRI) provided monthly rate of return data for each firm. 
Table 3

Excess Returns Case I:

Council Recommendation as the First Announcement

\begin{tabular}{|c|c|}
\hline Variable & Coefficient ( $t$-statistic) \\
\hline Constant $\left(\alpha_{0}\right)$ & $0.221(0.371)$ \\
\hline JANt $\left(\alpha_{1}\right)$ & $2.243(1.349)$ \\
\hline $\operatorname{DUM}_{1}\left(\alpha_{2}\right)$ & $0.742(0.768)$ \\
\hline $\mathbf{R}_{\operatorname{mat}}\left(\beta_{1}\right)$ & $1.025(9.022)^{* *}$ \\
\hline $\mathbf{R}_{\mathbf{m}}\left(\beta_{2}\right)$ & $-0.024(-0.087)$ \\
\hline \multicolumn{2}{|c|}{$\Gamma_{\mathrm{j}}:$ abnormal returns } \\
\hline September 1974 & $2.102(0.377)$ \\
\hline October 1974 & $-5.147(-0.866)$ \\
\hline November 1974 & $-3.152(-0.526)$ \\
\hline December 1974 & $5.284(0.944)$ \\
\hline January 1975 & $-0.505(-0.088)$ \\
\hline February 1975 & $-2.975(-0.508)$ \\
\hline March 1975 & $-3.145(-0.562)$ \\
\hline April 1975 & $15.511(2.848)^{* * *}$ \\
\hline May 1975 & $10.112(1.831)^{*}$ \\
\hline June 1975 & $-6.217(-1.123)$ \\
\hline $\begin{array}{l}\mathrm{R}^{2}=0.459 \\
\mathrm{~F}_{1 \times 145}=8.787\end{array}$ & \\
\hline
\end{tabular}

$\mathrm{t}$ - statistics are in parentheses; ** indicates significance at the $1 \%$ level, * significance at the $10 \%$ level. The Japan Security Research Institute provided monthly rate of return data for each firm. 
Table 4

Excess Returns Case II:

Bill Submission as the First Announcement

\begin{tabular}{|c|c|}
\hline Variable & Coefficient (t-statistic) \\
\hline Constant $\left(\alpha_{0}\right)$ & $0.255(0.444)$ \\
\hline $\mathrm{JAN}_{\mathrm{t}}\left(\alpha_{1}\right)$ & $2.249(1.417)$ \\
\hline $\operatorname{DUM}_{1}\left(\alpha_{2}\right)$ & $0.708(0.747)$ \\
\hline $\mathbf{R}_{\mathrm{m}}\left(\boldsymbol{\beta}_{1}\right)$ & $1.017(9.405)^{* *}$ \\
\hline$R_{\operatorname{mx}} \operatorname{DUM}_{\mathrm{t}}\left(\beta_{2}\right)$ & $-0.016(-0.058)$ \\
\hline \multicolumn{2}{|c|}{$\Gamma_{j}:$ abnormal returns } \\
\hline February 1975 & $-2.974(-0.512)$ \\
\hline March 1975 & $-3.144(-0.566)$ \\
\hline April 1975 & $15.712(2.873)^{* *}$ \\
\hline May 1975 & $10.112(1.847)^{*}$ \\
\hline June 1975 & $-6.217(-1.133)$ \\
\hline
\end{tabular}

$\mathrm{t}$ - statistics are in parentheses; ** indicates significance at the $1 \%$ level, * significance at the $10 \%$ level. The Japan Security Research Institute provided monthly rate of return data for each firm. 
Table 5

The Share of 16 Pharmaceutical Companies in the Trading Volume of the Tokyo Stock Exchange

\begin{tabular}{|c|c|c|c|}
\hline \multirow{2}{*}{ Month } & Trade Volumes (in thousands) & \multicolumn{2}{|c|}{ Share of Pharm. Firms } \\
\hline & 16 Phar. Firms(A) & Market Total(B) & $(A / B) * 100$ \\
\hline \multicolumn{4}{|l|}{ (1973) } \\
\hline August & 12,616 & $3,176,212$ & 0.397 \\
\hline September & 25,097 & $1,905,573$ & 1.317 \\
\hline October & 45,988 & $2,966,350$ & 1.550 \\
\hline November & 23,099 & $5,573,521$ & 0.414 \\
\hline December & 19,685 & $4,376,325$ & 0.450 \\
\hline \multicolumn{4}{|l|}{ (1974) } \\
\hline January & 64,846 & $3,923,018$ & 1.653 \\
\hline February & 43,515 & $3,557,224$ & 1.223 \\
\hline March & 51,281 & $3,344,568$ & 1.533 \\
\hline April & 97,237 & $5,465,040$ & 1,779 \\
\hline May & 41,026 & $8,582,880$ & 0.478 \\
\hline June & 25,423 & $4,494,600$ & 0.566 \\
\hline July & 37,548 & $4,531,514$ & 0.829 \\
\hline August & 44,310 & $3,800,234$ & 1,166 \\
\hline September & 35,485 & $2,172,104$ & 1.634 \\
\hline October & 21,284 & $3,295,575$ & 0.1546 \\
\hline November & 23,564 & $4,004,415$ & 0.589 \\
\hline December & 35,847 & $2,764,577$ & 1.297 \\
\hline \multicolumn{4}{|l|}{ (1975) } \\
\hline January & 72,093 & $2,831,312$ & 2.546 \\
\hline February & 76,546 & $5,266,096$ & 1.454 \\
\hline March & 60,116 & $4,908,144$ & 1.225 \\
\hline April & 151,611 & $4,689,192$ & 3.233 \\
\hline May & 272,548 & $5,135,112$ & 5.308 \\
\hline June & 100,319 & $3,877,992$ & 2.587 \\
\hline July & 85,099 & $3,792,958$ & 2.244 \\
\hline August & 43,965 & $2,702,050$ & 1.627 \\
\hline
\end{tabular}

Data on trading volume were obtained from various issues of Nihon Keizai Shimbun. 
Table 6

Results from the Seemingly Unrelated Regressions Analysis

\begin{tabular}{|c|c|c|c|}
\hline \multirow[b]{2}{*}{ Drug Firm } & \multicolumn{2}{|c|}{ Excess Return } & \multirow[b]{2}{*}{ April75 + May75 } \\
\hline & April75 & May75 & \\
\hline SANKYO & $4.679(0.584)$ & $-0.782(-0.097)$ & \\
\hline TAKEDA & $0.399(0.053)$ & $-1.741(-0.232)$ & \\
\hline YAMANOUCHI & $19.743(2.473)^{*}$ & $10.167(1.272)$ & 29.910 \\
\hline DAIICHI & $23.385(2.733)^{* *}$ & $6.554(0.765)$ & \\
\hline DAINIPPON & $9.375(1.008)$ & $7.6666(0.824)$ & 17.041 \\
\hline SHIONOGI & $44.843(5.753)^{* *}$ & $14.163(1.815)^{*}$ & 59.006 \\
\hline TANABE & $6.410(0.735)$ & $5.095(0.584)$ & 11.505 \\
\hline YOSHITOMI & $15.324(1.604)$ & $-1.684(-0.176)$ & 13.640 \\
\hline FUJISAWA & $30.385(3.721)^{* *}$ & $27.682(3.386)^{* * *}$ & 58.067 \\
\hline BANYU & $10.952(1.605)$ & $13.559(1 . .985)^{*}$ & 24.511 \\
\hline NIPPON SHIN. & $43.434(3.828)^{* *}$ & $17.093(1.505)$ & 60.527 \\
\hline CHUGAI & $1.382(0.097)$ & $-3.653(-0.255)$ & -2.271 \\
\hline GREEN CROSS & $9.307(0.817)$ & $14.354(1.259)$ & 23.661 \\
\hline EISAI & $10.076(0.968)$ & $13.342(1.281)$ & 23.418 \\
\hline ROHTO & $10.981(1.520)$ & $25.534(3.531)^{* *}$ & 36.515 \\
\hline TAISHO & $12.368(1.463)$ & $15.860(1.874)^{*}$ & 28.228 \\
\hline
\end{tabular}


Table 7

Coefficients of Explanatory Variables of Excess Returns

\begin{tabular}{llll}
\hline & A & B & C \\
\hline RATIO & 343.29 & 339.94 & 393.20 \\
& $(1.211)$ & $(1.228)$ & $(1.380)$ \\
PATENT & -0.0258 & & -0.0168 \\
& $(-1.153)$ & & $(-0.902)$ \\
R\&DPRO & & & -119.58 \\
& & -162.73 & $(-1.098)$ \\
CONSTANT & 15.211 & $(-1.168)$ & 22.137 \\
& $(0.979)$ & 24.330 & $(1.329)$ \\
\hline R & & $(1.487)$ & \\
F & & & 0.2587 \\
& 0.1841 & 0.2084 & 1.396 \\
& 1.467 & 1.711 & $(3,12)$ \\
\hline
\end{tabular}

t-statistics are in parentheses. R\&D and sales data for individual firms were obtained from the financial statements of each company. Process patent data were obtained from the Japan Patent Information Organization. 


\section{FOOTNOTES}

1. A government may adopt stronger protection even when some domestic industries decline if the stronger protection is part of an international exchange which includes other measures that stimulate other domestic industries. Similarly, obligations under international treaties and conventions may prompt adoption of stronger protection even when it is not in the country's interest if adoption of the entire package is in the country's interests.

2. It also made foreigners ineligible for patents; this restriction was removed in 1899 to allow Japan to join the Paris Convention, an international treaty promoting harmonization of patent systems across countries.

3. Although each member of the Diet has the right to draft a bill and submit it to the Diet, this happens infrequently in Japan.

4. Events can be a stock split, a dividend change, a merger and acquisition (M\&A) of firms, new regulations, accidents, and so on.

5. The definition of the rate of return is capital gain (loss) plus dividend payment divided by the last period's stock price.

6. Here we assume that the stock market is informationally efficient, that all publicly available information is incorporated into the price of a stock. This means that investors cannot earn excess returns from trading based on any publicly available information. Sakakibara et al. (1985) conduct several tests for informational efficiency and conclude that their "evidence supporting the informational efficiency ... outweighs the evidence against efficiency" (p. 137).

7. This model was first used by Fama, Fisher, Jensen, and Roll (1969) in a paper that inferred market efficiency from the manner in which the market absorbed information about stock splits into stock prices. Examples of recent applications are Binder (1985) on the ability of event studies to detect the effect of regulation; Chalk (1986) on the cost of a highly publicized 1979 DC-10 crash to shareholders of McDonnell Douglas; Smith, Bradley, and Jarrell (1986) on the relationship between petroleum firms' operating characteristics and their stockholders' capital gains and losses from the 1974 oil crisis and the subsequent U.S. oil price controls; Jarrell and Poulsen (1989) on insider trading prior to tender offers; Schumann on state regulation of takeovers; and Prager (1989) on the effect of the Interstate Commerce Act on the railroad industry.

8. Brealey and Myers (1984), pp. 117-192 offer a concise introduction to the relationship between risk and return in financial markets. Sakakibara, et al. (1988), ch. 1 find that the necessary conditions for applying the market model hold for the Tokyo Stock Exchange. They (p. 25) caution, however, that the beta coefficients for stocks listed in Tokyo vary more over time than the beta coefficients for stocks listed on the New York Stock Exchange.

9. Small firm returns are significantly higher than large firm returns during January in both the United States and Japan. Keim (1983), Tinic and West (1984), Jaffe and Westerfield (1985), and Kato and Schallheim (1985) document the "January effect" for Japan. Gultekin and Gultekin (1983) provide evidence for the January effect in other countries' stock markets.

10. Binder (1985) and Chalk (1986) are examples of single event studies. 
11. Our analysis considers only the relatively large firms in the Japanese pharmaceutical industry, as smaller firms are not traded on the Tokyo Stock Exchange.

12. The data after January 1980 are not used to avoid the possible noise due to the regulatory drug price change which started in June 1980. The regulatory change was designed to give a more innovative drug a higher reimbursement price than other drugs. Regressions were also run using data until December 1978. The results are similar to those reported here.

13. The F-statistic in Case $I$ is 0.498 with degrees of freedom 8 and 145. For Case II, it is 0.580 with 3 and 150.

14. To examine the possibility that the council's recommendation was anticipated and incorporated into stock prices prior to its publication, excess returns for four months prior to September 1974 were calculated in the same manner.

\begin{tabular}{lr} 
Date & Excess Returns (T-statistics) \\
\hline May 1974 & $-9.611(-1.729)$ \\
June 1974 & $1.445(0.260)$ \\
July 1974 & $1.817(0.322)$ \\
August 1974 & $4.532(0.762)$
\end{tabular}

We conclude from these results that the recommendation was not incorporated into pharmaceutical stock prices prior to its publication.

15. We modify Jarrell and Poulsen's procedure by normalizing the trading volume of individual firms by the market trading volume. This controls for spurious results due to changes in market trading volume during the analysis period.

16. For May: $F(16,139)=2.101$. For April: $F(16,139)=3.762$. For April and May: $F(32,278)=2.78$.

17. We recognize that patents are a poor proxy for the value of output from research and development activities, while expenditures on R\&D provide a relatively good measure of inputs into the R\&D process. See Trajtenberg (1990) and the references therein for a good discussion of these issues.

18. See La Croix (1991a) for an application of the economic theory of regulation to intellectual property rights.

19. See La Croix (1991b) for an analysis of the harmonization of intellectual property rights protecting computer software in the United States and Japan. 